\title{
SOIL SURFACE-ACTIVE FAUNA IN DEGRADED AND RESTORED LANDS OF NORTHEAST BRAZIL
}

\author{
Ademir Sérgio Ferreira de Araújo ${ }^{1 *}$, Nico Eisenhauer ${ }^{2}$, Luís Alfredo Pinheiro Leal Nunes ${ }^{1}$, Luiz Fernando Carvalho Leite ${ }^{3}$, \\ Simone Cesarz ${ }^{2}$ \\ ${ }^{1}$ Soil Quality Lab., Agricultural Science Center, Federal University of Piauí, Teresina, PI, Brazil \\ ${ }^{2}$ Institute of Ecology, Friedrich-Schiller-University Jena, Dornburger Straße 159, 07743 Jena, Germany \\ ${ }_{3}^{3}$ Embrapa Mid-North, Av. Duque de Caxias, Teresina, PI, Brazil
}

Received: 21 May 2013; Revised: 13 August 2013; Accepted: 13 August 2013

\begin{abstract}
Land degradation reducing vegetation cover may affect the soil surface-active fauna because both aboveground and belowground invertebrates depend on complex plant communities. In this study, we evaluated the effect of land degradation and restoration on soil fauna in northeast Brazil. Sites differed in degradation status: native vegetation, moderately degraded land, highly degraded land, and land under restoration for 4 years. Araneae and Coleoptera densities were significantly higher in natural vegetation and restored land ( $8 \pm 4$ ind./trap and $41 \pm 21$ ind./trap, respectively) than in degraded lands $(-73 \%$ and $-81 \%$, respectively). The density of Formicidae was significantly higher in natural vegetation (206 \pm 181 ind./trap) than in highly degraded land (32 \pm 24 ind./trap), while restored land (51 \pm 10 ind./trap) and moderately degraded land (37 \pm 14 ind./trap) did not differ significantly from the other degradation levels. The density of Orthoptera did not follow the aforementioned patterns, while invertebrate groups mostly had highest densities in natural land and restored land. Linear regressions showed a strong negative relation between faunal density and soil bulk density, and a positive relation with soil organic matter due to an increase in plant cover. Our results indicate that land degradation simplifies soil surface-active invertebrate communities with pronounced decreases in the density of Araneae, Coleoptera, and Formicidae, but that land restoration practices may recover the density of soil fauna even after only 4 years. Araneae, Coleoptera, and Formicidae respond sensitively to land degradation and restoration practice and are suggested as indicator groups for restoration success. Copyright @ 2013 John Wiley \& Sons, Ltd.
\end{abstract}

KEYWORDS: indicator taxa; land degradation; monitoring; pitfall traps; restoration practices; soil arthropods

\section{INTRODUCTION}

The land surface affected by anthropogenic degradation is increasing. Approximately $23 \%$ of all arable land of the planet is being affected by land degradation, and, at the end of the last century, approximately 910 Mha were under moderate to extreme degradation (Oldeman, 1994). In Brazil, slashand-burn practices combined with diamond-mining activities have caused land degradation (Almeida-Filho \& Carvalho, 2010; Thomaz \& Luiz, 2012; Souza Braz et al., 2013). In addition, high temperatures and evapotranspiration associated with a short rainy period with high precipitation in this region and fragile soils may intensify the effects of anthropogenic land degradation.

The Brazilian Government has invested about U\$ 1 million for the purpose of recovery of degraded land. The main goal is to restore soil properties and increase the vegetation cover as important strategies for the recovery of soil productivity and sustainability (Araujo et al., 2013). The restoration process involves the use of conservation practices, such as building terraces for water storage and the sowing of plant species, such as grasses and legumes. Previous studies found increasing vegetation cover to improve the chemical and

\footnotetext{
* Correspondence to: A. S. F. Araújo, Department of Soil Science and Agricultural Engineering, Federal University of Piauí, Campus of Socopo, 64050-550, Teresina, PI, Brazil.

E-mail: asfaruaj@yahoo.com.br
}

physical properties of soils (Silva et al., 2012; Trabaquini et al., 2013) as well as soil microbial biomass and enzyme activity (Nunes et al., 2012; Wu et al., 2013).

Despite the high density and biodiversity of soil-dwelling animals, limited knowledge exists of the consequences of land degradation and restoration on different groups of soil animals. Wall et al. (2010) recently concluded that conservation and management attempts to protect biodiversity from ecosystem degradation have mainly focused on the loss of aboveground species, while soil organisms may vanish unnoticed. As soil organisms drive many essential ecosystem processes (e.g., Wardle et al., 2004; Cerdà \& Doerr, 2010; Cerdà \& Jurgensen, 2011; García-Orenes et al., 2012), land management practices thus should also consider promoting soil biodiversity and high population densities of soil-dwelling organisms in order to improve sustainable crop production, soil fertility, and nutrient and water retention (Wall et al., 2010).

The soil surface-active fauna can provide important information on the degree of land degradation or restoration due to its strong dependency on vegetation properties (Scherber et al., 2010; Eisenhauer et al., 2013). We investigated land degradation and restoration effects on the densities of soil surface-active fauna in northeast Brazil across different seasons and years. We expected land degradation to strongly reduce the densities of many groups of invertebrates, and we were interested in the question if current restoration approaches are able to successfully reconstitute such invertebrate communities. 
Moreover, the identification of sensitive invertebrate indicator groups may inform rapid assessment approaches to evaluate the biological status of degraded and restored lands.

\section{MATERIALS AND METHODS}

\section{Study Site}

The study was conducted at Gilbués municipality $\left(09^{\circ} 49^{\prime} 55^{\prime \prime} \mathrm{S}\right.$ and $45^{\circ} 20^{\prime} 38^{\prime \prime} \mathrm{W}$ ), northeast Brazil. The climate is tropical dry with a mean precipitation of $1,000 \mathrm{~mm} \mathrm{yr}^{-1}$ (with rainfall from January through May) and an annual mean temperature of $31^{\circ}$ $\mathrm{C}$, with minimum and maximum temperatures of 22 and $40^{\circ} \mathrm{C}$, respectively. According to the Brazilian soil survey, the dominant soils are classified as eutrophic red-yellow podzolic soils with low activity clay and granite, and gneiss as parental material. The following four selected sites $\left(4,000 \mathrm{~m}^{2}\right.$ each) were studied: native vegetation (NAT), moderately degraded land (MDL), highly degraded land (HDL), and land under restoration (RES) (Table I).

The native vegetation is covered by trees, including Cenostigma macrophyllum Tul., Tabebuia serratifolia (Vahl) G. Nicholson, Hymenaea courbaril L., Orbignya phalerata Mart., Combretum leprosum Mart., Guarea kunthiana A. Juss, and Lecythis pisonis Camb. These trees cover between 80 and $90 \%$ of the ground surface and contribute approximately $1 \mathrm{~kg}$ $\mathrm{m}^{-2}$ of plant litter annually (Figure 1a). The MDL (Figure 1c) and HDL (Figure 1d) sites resulted from cutting of native vegetation for charcoal production in 2008 and 2004, respectively. Nowadays, the MDL site is dominated by herbaceous plant species (Aristida sepfolia L., Cyperus uncynulatus L., and Tragus berteronianus L.) that cover approximately $24 \%$ of the soil surface, while the HDL site has sparse vegetation cover $(<5 \%)$. Land restoration at RES (Figure $1 \mathrm{~b})$ started in 2006 by shifting the degraded land by building terraces (approximately $500 \mathrm{~m}^{2}$ ) for water storage, fertilization of the soil with 50, 100, and $200 \mathrm{~kg} \mathrm{ha}^{-1} \mathrm{yr}^{-1}$ of $\mathrm{N}, \mathrm{K}_{2} \mathrm{O}$, and $\mathrm{P}_{2} \mathrm{O}_{5}$, respectively. The fertilizers are applied annually by spreading on the soil surface. Afterwards, the RES site was re-vegetated with Crotalaria juncea L. and Panicum maximum Jacq. at densities of 2,500 and 3,000 plants ha ${ }^{-1}$, respectively. The annual input of litter (air-dried) from the catch crops is approximately $1.5 \mathrm{~kg} \mathrm{~m}^{-2}$ on the soil surface.

\section{Sampling of Soil Surface-Active Fauna}

Surface-active soil fauna was evaluated in March (wet season) and September (dry season) of 2010 and 2011 using pitfall traps, consisting of plastic containers of $10 \mathrm{~cm}$ height and $10 \mathrm{~cm}$ in diameter with $50 \%$ ethanol to about $1 / 3$ of its volume. These traps were buried leaving its opening at ground level, spaced $20 \mathrm{~m}$ in the form of a transect towards the central part of each area, where they remained for 7 days. At each site, we brought out six traps to cover some spatial heterogeneity. The soil fauna was identified and quantified with a binocular microscope and grouped to order or family level.

\section{Site Properties}

Soil organic matter (SOM) was determined by the wet combustion method using a mixture of potassium dichromate and sulfuric acid under heating (Yeomans \& Bremner, 1988). Soil bulk density (SBD) was determined using a volumetric sampling tool that had a relief cutting tip of $50 \mathrm{~mm}$ diameter, which screwed on to a $150 \mathrm{~mm}$ long cylinder. The cylinders were inserted by hand using gentle pressure and were not used if any compaction occurred during insertion. SBD was calculated according to Logsdon \& Karlen (2004). Vegetation cover was estimated by assessing the percentage of the ground that it was covered by the existing vegetation.

\section{Statistical Analyses}

Data were $\log _{10}$-tranformed to meet the requirements for parametric statistical tests. Only those invertebrate groups

Table I. Main characteristic of the evaluated sites: native vegetation, moderately degraded land, highly degraded land, and land under restoration for 4 years

\begin{tabular}{|c|c|c|c|c|}
\hline Characteristic & NAT & RES & MDL & HDL \\
\hline Longitude & $45^{\circ} 20^{\prime} 42 \cdot 7^{\prime \prime} \mathrm{W}$ & $45^{\circ} 20^{\prime} 32 \cdot 2^{\prime \prime} \mathrm{W}$ & $45^{\circ} 20^{\prime} 41 \cdot 1^{\prime \prime} \mathrm{W}$ & $45^{\circ} 20^{\prime} 29 \cdot 2^{\prime \prime} \mathrm{W}$ \\
\hline Latitude & $09^{\circ} 52^{\prime} 32 \cdot 1^{\prime \prime} \mathrm{S}$ & $09^{\circ} 52^{\prime} 49 \cdot 6^{\prime \prime} \mathrm{S}$ & $09^{\circ} 52^{\prime} 33 \cdot 0^{\prime \prime} \mathrm{S}$ & $09^{\circ} 52^{\prime} 48 \cdot 3^{\prime \prime} \mathrm{S}$ \\
\hline Altitude (m) & 441 & 449 & 460 & 452 \\
\hline Slope $(\%)$ & $2-5$ & $5-9$ & $5-9$ & $5-9$ \\
\hline Vegetation & zTrees $^{\mathrm{a}}$ & Herbs $^{b}$ & $\mathrm{Herbs}^{\mathrm{c}}$ & Herbs $^{\mathrm{d}}$ \\
\hline Clay $\left(\mathrm{g} \mathrm{kg}^{-1}\right)$ & $510 \cdot 2$ & $510 \cdot 8$ & $500 \cdot 4$ & $520 \cdot 1$ \\
\hline Silt $\left(\mathrm{g} \mathrm{kg}^{-1}\right)$ & $90 \cdot 7$ & $100 \cdot 3$ & $100 \cdot 5$ & $90 \cdot 8$ \\
\hline Sand $\left(\mathrm{g} \mathrm{kg}^{-1}\right)$ & $390 \cdot 1$ & $370 \cdot 9$ & $390 \cdot 1$ & $380 \cdot 1$ \\
\hline $\mathrm{SBD}^{\mathrm{e}}\left(\mathrm{g} \mathrm{cm}^{-3}\right)$ & $1 \cdot 15$ & $1 \cdot 23$ & $1 \cdot 38$ & $1 \cdot 40$ \\
\hline $\operatorname{SOM}^{\mathrm{f}}\left(\mathrm{g} \mathrm{kg}^{-1}\right)$ & $22 \cdot 6$ & $10 \cdot 4$ & $5 \cdot 8$ & $2 \cdot 1$ \\
\hline Vegetation cover (\%) & 100 & 100 & 24 & 4 \\
\hline
\end{tabular}

$\mathrm{NAT}=$ native vegetation, $\mathrm{MDL}=$ moderately degraded land, $\mathrm{HDL}=$ highly degraded land, $\mathrm{RES}=$ restored land .

${ }^{a}$ Caneleiro (Cenostigma macrophyllum L.), pau d'arco (Tabebuia serratifolia L.), jatobá (Hymenaea courbaril L.), palmeira de babaçu (Orbignya phalerata L.), mofumbo (Combretum leprosum L.), jitó (Guarea kunthiana L.), and sapucaia (Lecythis pisonis L.).

${ }^{\mathrm{b}}$ Crotalaria juncea L. and Panicum maximum L.; $24 \%$ total plant cover

${ }^{\mathrm{c}}$ Aristida sepfolia L., Cyperus uncynulatus L., and Tragus berteronianus L.; $5 \%$ total plant cover

${ }_{\mathrm{d}}^{\mathrm{h}}$ erbs (Tragus berteronianus L.).

${ }^{\mathrm{e}} \mathrm{SBD}$, soil bulk density

${ }^{\text {f }} \mathrm{SOM}$, soil organic matter (compared with native vegetation). 

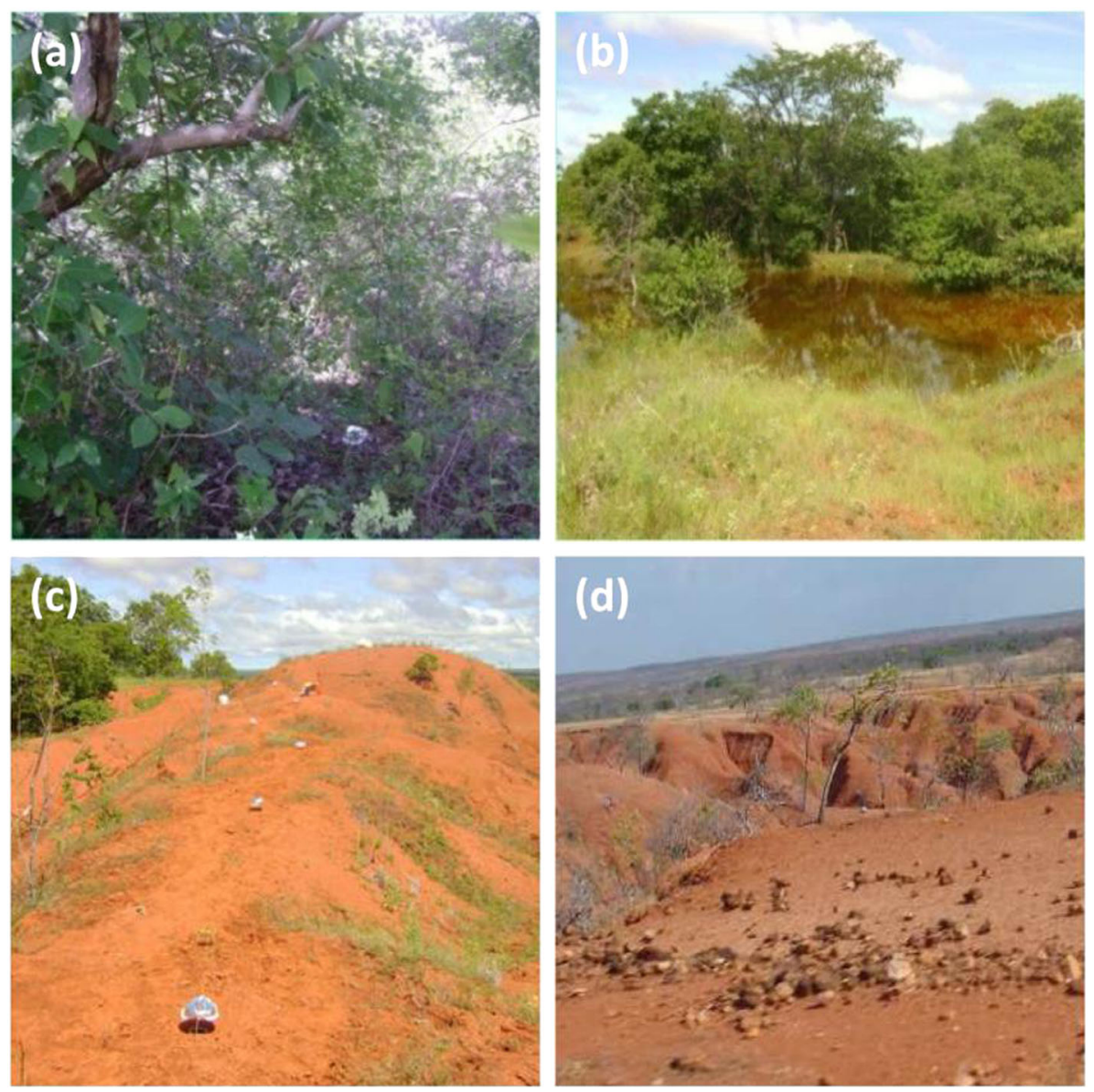

Figure 1. The study sites. (a) Natural vegetation dominated by trees covering between $80 \%$ and $90 \%$ of the ground surface. (b) Restored land; land restoration started in 2008 by shifting the degraded land by building terraces (approximately $500 \mathrm{~m}^{2}$ ) for water storage. (c) Moderately degraded land and (d) highly degraded land resulting from cutting of native vegetation for charcoal production in 2008. This figure is available in colour online at wileyonlinelibrary.com/ journal/ldr.

were analyzed that met the statistical assumptions, were available in high numbers and for which the sampling method was adequate (i.e., Araneae, Coleoptera, Formicidae, Orthoptera). Generally, soil-dwelling organisms (e.g., Collembola, Acari) are extracted from soil cores by heat (Macfadyen, 1961; Kempson et al., 1963), Heteroptera and Homoptera live in the vegetation and are investigated using sucking methods or spoon nets (Sanders \& Entling, 2011), whereas flying organisms are trapped with further techniques depending on their behavior (e.g., stick and pheromone traps). Therefore, most of the taxa were not assessed adequately with pitfall traps and are excluded from further analyses. The means and standard deviations of these groups are nevertheless given in Table II. We used repeated measures analysis to investigate land degradation and seasons on the densities of soil surface-active fauna. In addition to repeated measures analyses, we performed comparisons of means using Tukey's honestly significant difference tests.

Linear regressions were calculated using data on SBD $\left(\mathrm{g} \mathrm{cm}^{-3}\right)$ and SOM (\%). Data on bulk density were logtransformed, and for SOM data, we used arcsin-transformation. All statistical analyses were performed using SAS 9.3 (SAS Institute Inc., Cary, NC, USA).

\section{RESULTS}

In general, we found very strong effects of land degradation on the density of Araneae (mainly vagrant species; $F_{3,20}=20 \cdot 29$, $p<0.001$ ), Coleoptera (mainly Scarabaeidae; $F_{3,20}=85.15$, $p<0.001$ ), and Formicidae (only Atta spec.; $F_{3,20}=4.93$, $p=0.01$ ), but less so in Orthoptera (only Gryllidae; $F_{3,20}=2 \cdot 49, p=0 \cdot 09$; Figure 2). Araneae and Coleoptera densities were significantly higher in natural vegetation and restored land than in degraded lands (Figure 2, graphs a and b). Similarly, the density of Formicidae was significantly higher in natural vegetation than in strongly degraded land, while restored land and moderately degraded land did not differ from the other degradation levels (Figure 2c). The density of Orthoptera did not differ significantly between degradation levels, their densities remained stable, and did not follow the aforementioned trend to decrease with increasing degradation level (Figure 2d).

Densities of Araneae, Coleoptera, Formicidae, and Orthoptera differed significantly with time and the interaction of time and degradation level; however, consistent patterns were not observed (Tables III and IV). For instance, Araneae (and other taxa) were most often highest in NAT and RES plots compared with MDL and HDL but differed between seasons. Depending 
(a)

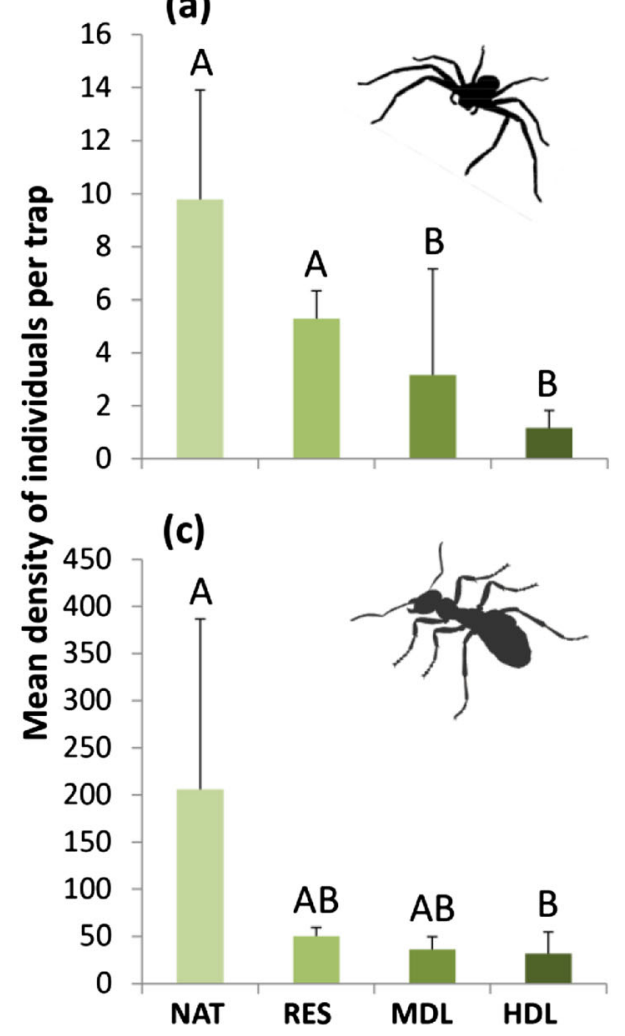

(b)

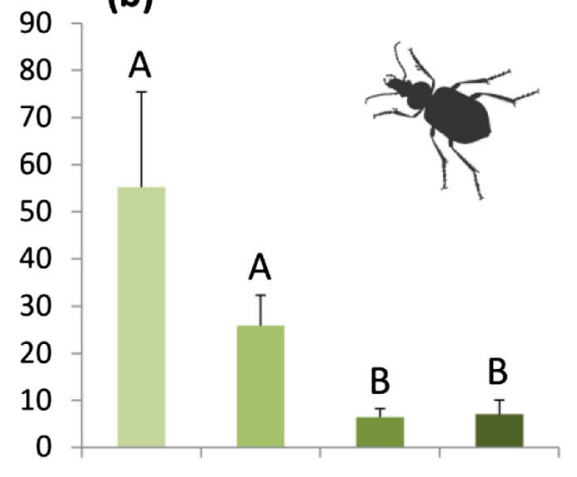

(d)

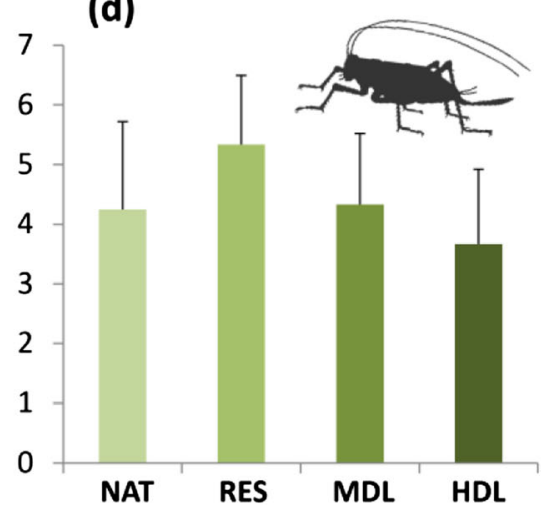

Figure 2. Soil surface-active fauna [(a) Araneae, (b) Coleoptera, (c) Formicidae, (d) Orthoptera $]$ as affected by land degradation; MDL = moderately degraded land; HDL = highly degraded land), land restoration (RES) in comparison to natural vegetation (NAT). Bars with different letters vary significantly (Tukey's honestly significant difference test, $p<0 \cdot 05$ ). This figure is available in colour online at wileyonlinelibrary.com/journal/ldr.

on the year, densities were higher in the dry or the wet season. In addition, in plots with native vegetation during the dry season of 2011, densities of Araneae were about 400\% higher than the overall mean of the remaining dates. Similar results were observed for Formicidae but not for Coleoptera and Orthoptera (Table III). Linear regression revealed strong relationships of bulk density and SOM with densities of Araneae, Coleoptera, and Formicidae, whereas Orthoptera were not significantly affected (Table V). Densities of soil surface-active fauna decreased with increasing SBD, whereas the opposite was true for SOM.

\section{DISCUSSION}

In the present study, we investigated the response of soil surface-active fauna to explore the consequences of land degradation for soil fauna. In addition, we suggest indicator groups for restoration success. We focused on the most abundant taxa Araneae, Coleoptera, Formicidae and Orthoptera, which were adequately assessed in the present study and showed relatively high population densities. With the exception of Orthoptera, these taxa were strongly affected by land degradation and their densities declined significantly with increasing land degradation, (Lavelle et al., 2001) likely because of the loss of vegetation cover and thus an adequate habitat (Menta et al., 2011). The planting and fertilization of degraded lands successfully restored plant cover, which in turn allowed the recovery of invertebrate communities.
Densities of Araneae and Coleoptera in restored land did not differ significantly from land with native vegetation indicating a general recovery of densities and note that we did not assess faunal diversity. In detail, spiders respond to changes in microclimatic conditions (Pearce et al., 2004), depend on structural complexity of the vegetation (Uetz, 1991; Langellotto \& Denno, 2004), and prey occurrence (Wise \& Chen, 1999; Cunha Neto et al., 2012). The latter is also supported by our data with overall lower densities of invertebrates in degraded lands.

The increase in the densities of beetles, mainly Scarabaeidae, in restored lands compared with degraded land may also correspond to an overall resource increase as they live on carrion, dead and living plant material, and are generally linked to higher organic matter availability (Kim, 1993; Fagundes et al., 2011).

All ants in our pitfall traps belonged to the genus Atta, which have a mutualistic association with fungi, which are grown in specific fungus gardens delivering food for the ants (Weber, 1966). Although Atta cuts plant leaves for maintaining the fungus gardens, the net effect on the vegetation often is positive with higher vegetation cover in the presence of ants (Trager et al., 2010). Thus, increased ant densities may be due to higher resource availability in restored lands.

All Orthoptera in pitfall traps were Gryllidae. This group did not respond significantly to land degradation suggesting no strong relationship to vegetation cover. Gryllidae are omnivorous scavengers feeding on a wide range of organic 
SOIL SURFACE-ACTIVE FAUNA IN DEGRADED LANDS

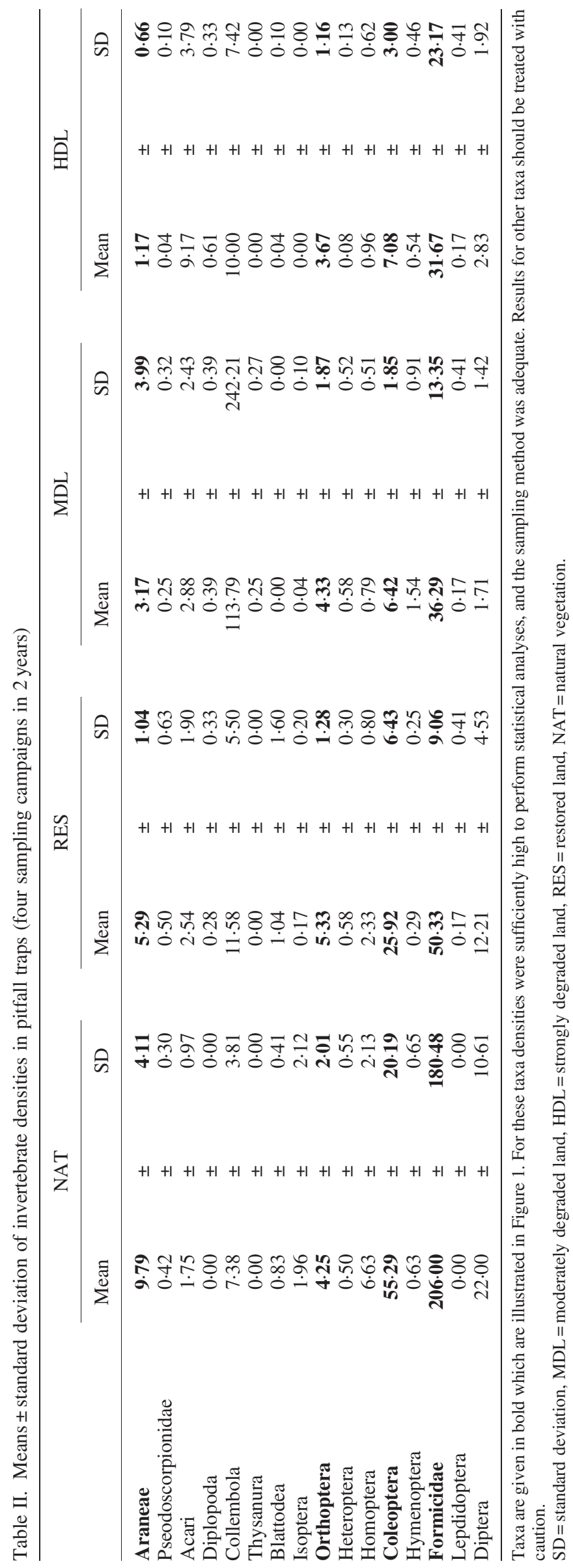




\section{A. S. F. DE ARAÚJO ET AL.}

Table III. Means \pm standard deviation of soil surface-active animal densities trapped with pitfall traps in two seasons (rain and dry) in 2 years (2010 and 2011)

\begin{tabular}{|c|c|c|c|c|c|c|c|c|c|c|c|c|c|c|}
\hline & & & \multicolumn{3}{|c|}{ Araneae } & \multicolumn{3}{|c|}{ Coleoptera } & \multicolumn{3}{|c|}{ Formicidae } & \multicolumn{3}{|c|}{ Orthoptera } \\
\hline & & & Mean & & SD & Mean & & SD & Mean & & SD & Mean & & SD \\
\hline \multirow[t]{8}{*}{2010} & rain & NAT & 3.83 & \pm & $1 \cdot 17$ & 58.67 & \pm & 15.07 & $29 \cdot 17$ & \pm & 11.44 & $7 \cdot 33$ & \pm & 4.89 \\
\hline & & RES & $8 \cdot 33$ & \pm & 3.88 & $24 \cdot 50$ & \pm & 9.91 & $65 \cdot 50$ & \pm & $25 \cdot 19$ & 5.67 & \pm & $5 \cdot 16$ \\
\hline & & LDL & 1.50 & \pm & 1.05 & $5 \cdot 17$ & \pm & $5 \cdot 27$ & $46 \cdot 17$ & \pm & $26 \cdot 10$ & $4 \cdot 17$ & \pm & 2.64 \\
\hline & & HDL & 0.67 & \pm & 0.82 & $6 \cdot 33$ & \pm & $4 \cdot 32$ & $18 \cdot 83$ & \pm & 14.96 & $2 \cdot 50$ & \pm & 0.55 \\
\hline & dry & NAT & $7 \cdot 50$ & \pm & $2 \cdot 43$ & $65 \cdot 33$ & \pm & 21.68 & $19 \cdot 83$ & \pm & $7 \cdot 41$ & $2 \cdot 50$ & \pm & 3.08 \\
\hline & & RES & $5 \cdot 33$ & \pm & 2.94 & $21 \cdot 50$ & \pm & 4.59 & 68.83 & \pm & 27.97 & $6 \cdot 83$ & \pm & 2.48 \\
\hline & & LDL & $2 \cdot 83$ & \pm & $2 \cdot 56$ & $14 \cdot 33$ & \pm & 6.53 & 38.00 & \pm & 19.05 & $10 \cdot 17$ & \pm & 7.00 \\
\hline & & HDL & 0.33 & \pm & 0.52 & 16.67 & \pm & $10 \cdot 13$ & $31 \cdot 00$ & \pm & $12 \cdot 25$ & $5 \cdot 33$ & \pm & 3.44 \\
\hline \multirow[t]{8}{*}{2011} & rain & NAT & $3 \cdot 33$ & \pm & $2 \cdot 16$ & 95.83 & \pm & $58 \cdot 20$ & $24 \cdot 33$ & \pm & 12.77 & 5.00 & \pm & $2 \cdot 90$ \\
\hline & & RES & $2 \cdot 17$ & \pm & 1.72 & $27 \cdot 50$ & \pm & $13 \cdot 13$ & $24 \cdot 17$ & \pm & $13 \cdot 63$ & 6.83 & \pm & 5.49 \\
\hline & & LDL & $7 \cdot 00$ & \pm & 11.83 & $5 \cdot 83$ & \pm & $5 \cdot 27$ & $39 \cdot 17$ & \pm & $25 \cdot 61$ & $2 \cdot 33$ & \pm & 3.01 \\
\hline & & HDL & 0.33 & \pm & $0 \cdot 52$ & 4.67 & \pm & 3.93 & $11 \cdot 17$ & \pm & $5 \cdot 46$ & $5 \cdot 67$ & \pm & 3.01 \\
\hline & dry & NAT & $24 \cdot 50$ & \pm & $17 \cdot 47$ & $1 \cdot 33$ & \pm & 1.51 & $750 \cdot 67$ & \pm & $709 \cdot 23$ & $2 \cdot 17$ & \pm & 1.47 \\
\hline & & RES & $5 \cdot 33$ & \pm & $2 \cdot 34$ & $30 \cdot 17$ & \pm & 21.02 & $42 \cdot 83$ & \pm & $11 \cdot 65$ & $2 \cdot 00$ & \pm & 1.67 \\
\hline & & LDL & 1.33 & \pm & 1.86 & $0 \cdot 33$ & \pm & 0.52 & $21 \cdot 83$ & \pm & $15 \cdot 70$ & 0.67 & \pm & 1.21 \\
\hline & & HDL & $3 \cdot 33$ & \pm & $2 \cdot 34$ & 0.67 & \pm & 0.52 & $65 \cdot 67$ & \pm & $87 \cdot 70$ & $1 \cdot 17$ & \pm & 1.60 \\
\hline
\end{tabular}

$\mathrm{MDL}=$ moderately degraded land, $\mathrm{HDL}=$ highly degraded land, $\mathrm{RES}=$ restored land, $\mathrm{NAT}=$ natural vegetation, $\mathrm{SD}=$ standard deviation.

Table IV. ANOVA table of repeated measures analysis for densities of soil surface-active fauna in degraded lands and the respective interaction

\begin{tabular}{|c|c|c|c|c|c|c|}
\hline & \multicolumn{2}{|c|}{ DEG } & \multicolumn{2}{|c|}{ Time } & \multicolumn{2}{|c|}{ DEG $\times$ Time } \\
\hline & $\mathrm{F}_{3,20}$ & $\mathrm{P}$ & $\mathrm{F}_{3,60}$ & $\mathrm{P}$ & $\mathrm{F}_{9,60}$ & $\mathrm{P}$ \\
\hline Araneae & $20 \cdot 29$ & $<0.0001$ & $6 \cdot 51$ & 0.0007 & $5 \cdot 52$ & $<0.0001$ \\
\hline Orthoptera & 2.49 & $0 \cdot 0894$ & 11.92 & $<0.0001$ & 3.05 & $0 \cdot 0046$ \\
\hline Coleoptera & $85 \cdot 15$ & $<0.0001$ & $46 \cdot 04$ & $<0.0001$ & $10 \cdot 12$ & $<0.0001$ \\
\hline Formicidae & 4.93 & 0.0101 & $8 \cdot 17$ & $0 \cdot 0001$ & $7 \cdot 41$ & $<0 \cdot 0001$ \\
\hline
\end{tabular}

DEG; with natural vegetation, restored land, moderately degraded land and highly degraded land), time (wet and dry season in 2010 and 2011.

Table V. Linear regressions of soil surface-active fauna with soil bulk density $\left(\mathrm{g} \mathrm{m}^{-3}\right)$ and soil organic matter $(\%)$

\begin{tabular}{|c|c|c|c|c|c|c|}
\hline & \multicolumn{3}{|c|}{ Bulk density } & \multicolumn{3}{|c|}{ SOM } \\
\hline & $\mathrm{R}^{2}$ & $\mathrm{~T}_{1,22}$ & $\mathrm{P}$ & $\mathrm{R}^{2}$ & $\mathrm{~T}_{1,22}$ & $\mathrm{P}$ \\
\hline Aranae & 0.5676 & $-5 \cdot 37$ & $<0.0001$ & $0 \cdot 6525$ & $6 \cdot 43$ & $<0.0001$ \\
\hline Orthoptera & 0.0375 & -0.93 & $0 \cdot 3646$ & $0 \cdot 0015$ & $0 \cdot 18$ & 0.8562 \\
\hline Coleoptera & $0 \cdot 8148$ & -9.84 & $<0.0001$ & 0.7863 & 9 & $<0.0001$ \\
\hline Formicidae & 0.4868 & -4.57 & 0.0002 & 0.4318 & 4.09 & 0.0005 \\
\hline
\end{tabular}

$\mathrm{SOM}=$ soil organic matter.

materials, e.g., dead animals, living and decaying plant material, seedlings, and fungi (Dettner \& Peters, 2003). This food mixing makes them probably less sensitive to environmental changes (Hailey et al., 1998) and may explain their nonsignificant response to land degradation.

Overall, plants influence the soil surface-active fauna directly by providing a source of energy (i.e., carbon) in their surface litter and root inputs, and contribute indirectly by altering soil structure and hydrology, thereby influencing the microclimate experienced by soil organisms (Wolters, 2001). This is confirmed by linear regressions with SOM data. We observed a significant increase in the densities of soil surface-active soil fauna with increasing SOM content. In this context, an increase in SOM corresponds to an increase in plant biomass as indicated by higher plant cover with decreasing degradation level, i.e., high availability of food resources, and habitat. This is in line with previous studies on soil microorganisms reporting significant relationships between land degradation, reductions in soil pore structure, increased soil erosion, decreased SOM, and decreased soil microbial activity (García-Orenes et al., 2010; Guénon et al., 2013; Wu et al., 2013). Moreover, the relationships between SBD and soil surface-active fauna 
may indicate the importance of soil pores for the foraging behavior of some Araneae, Coleoptera, and Formicidae taxa, as well as that soil fauna may influence soil structure through burrowing activity (García-Orenes et al., 2010; Oo et al., 2013).

Although we grouped the focal taxa very roughly (order level), we were able to identify three possible indicator taxa reflecting the success of restoration practices. The assessment of indicator taxa is most often less destructive and labor-intensive than investigating whole communities at the species level (Niemelä \& Baur, 1998), which is why such rapid ecosystem assessments may be an easy monitoring tool to evaluate the consequences of, for instance, land degradation and restoration. Nevertheless, further studies in restored and degraded lands are needed to inspect if aggregation of soil surface-active species information into order level is appropriate and how the diversity of the focal taxa vary with land degradation and restoration.

\section{CONCLUSION}

Our results indicate that land degradation strongly decreases the density of Araneae, Coleoptera, and Formicidae, but that land restoration practices may increase the density of soil surface-active fauna even after only 4 years. The rapid assessment of these invertebrate groups may thus represent a powerful tool to evaluate the biological status of degraded and restored lands.

\section{ACKNOWLEDGEMENTS}

The authors are grateful to "Conselho Nacional de Desenvolvimento Científico e Tecnológico" (CNPq-Brazil) for financial support of this research. Ademir S.F. Araújo and Luiz F. Leite are supported by research fellowships from CNPq-Brazil (research productivity).

\section{REFERENCES}

Almeida-Filho R, Carvalho CM. 2010. Mapping land degradation in the Gilbues region, northeastern Brazil, using Landsat TM images. International Journal of Remote Sensing 31: 1087-1094.

Araujo ASF, Cezars S, Leite LFC, Borges CD, Tsai SM, Eisenhauer N. 2013. Soil microbial properties and temporal stability in degraded and restored lands of northeast Brazil. Soil Biology and Biochemistry 66: 175-181.

Cerdà A, Doerr SH. 2010 The effect of ant mounds on overland flow and soil erodibility following a wildfire in eastern Spain. Ecohydrology $\quad 3: 392-401$.

Cerdà A, Jurgensen MF. 2011. Ant mounds as a source of sediment on citrus orchard plantations in eastern Spain. A three-scale rainfall simulation approach. Catena 85: 231-236.

Cunha Neto FV, Correia MEF, Pereira GHA, Pereira MG, Leles PSS. 2012. Soil fauna as indicator of soil quality in forest stands, pastures and secondary forest. Revista Brasileira de Ciência do Solo 36: 1407-1417.

Dettner K, Peters W. 2003. Lehrbuch der Entomolgie, 2nd edn. Spektrum Akademischer Verlag: München.

Eisenhauer N, Dobies T, Cesarz S, Hobbie SE, Meyer RJ, Worm K, Reich PB. 2013. Plant diversity effects on soil food webs are stronger than those of elevated $\mathrm{CO}_{2}$ and $\mathrm{N}$ deposition in a long-term grassland experiment. Proceedings of the National Academy of Sciences 110: 6889-6894.

Fagundes CK, Di Mare RA, Wink C, Manfio D. 2011. Diversity of the families of Coleoptera captured with pitfall traps in five different environments in Santa Maria, RS, Brazil. Brazilian Journal of Biology 71: 381-390.

García-Orenes F, Guerrero C, Roldán A, Mataix-Solera J, Cerdà A, Campoy M, Zornoza R, Bárcenas G, Caravaca F. 2010. Soil microbial biomass and activity under different agricultural management systems in a semiarid Mediterranean agroecosystem. Soil \& Tillage Research 109: 110-115.

García-Orenes F, Roldán A, Mataix-Solera J, Cerdà A, Campoy M, Arcenegui V, Caravaca F. 2012. Soil structural stability and erosion rates influenced by agricultural management practices in a semi-arid Mediterranean agroecosystem. Soil Use and Management 28: 571-579.

Guénon R, Vennetier M, Dupuy N, Roussos S, Pailler A, Gros R. 2013. Trends in recovery of Mediterranean soil chemical properties and microbial activities after infrequent and frequent wildfires. Land Degradation \& Development 24: 115-128. DOI: 10.1002/ldr.1109

Hailey A, Chidavaenzi RL, Loveridge JP. 1998. Diet mixing in the omnivorous tortoise Kinixys spekii. Functional Ecology 12: 373-385.

Kempson D, Lloyd M, Ghelardi R. 1963. A new extractor for woodland litter. Pedobiologia 3: 1-21.

Kim KC. 1993. Biodiversity, conservation and inventory: why insects matter. Biodiversity and Conservation 2: 191-214.

Langellotto GA, Denno RF. 2004. Responses of invertebrate natural enemies to complex-structured habitats: a meta-analytical synthesis. Oecologia 139: 1-10.

Lavelle P, Barros E, Blanchart E, Brown G, Desjardins T, Mariani L. Ross J. 2001. SOM management in the tropics: why feeding the soil macrofauna?. Nutrient Cycling in Agroecosystems 61: 53-61.

Logsdon SD, Karlen DL. 2004. Bulk density as a soil quality indicator during conversion to no-tillage. Soil and Tillage Research 78: 143-149.

Macfadyen A. 1961. Improved funnel-type extractors for soil arthropods. Journal of Animal Ecology 30: 171-184.

Menta C, Leoni A, Gardi C, Conti FD. 2011. Are grasslands important habitats for soil microarthropod conservation? Biodiversity and Conservation 20: 1073-1087.

Niemelä J, Baur B. 1998. Threatened species in a vanishing habitat: plants and invertebrates in calcareous grasslands in the Swiss Jura mountains. Biodiversity and Conservation 7: 1407-1416.

Nunes JS, Araujo ASF, Nunes LAPL, Lima LM, Carneiro RFV, Salviano AAC, Tsai SM. 2012. Impact of land degradation on soil microbial biomass and activity in northeast Brazil. Pedosphere 22: 88-95.

Oldeman LR. 1994. The global extent of land degradation. In Land Resilience and Sustainable Land Use, Greenland DJ, Szabolcs I (eds). CABI: Wallingford; 99-118.

Oo AN, Iwai CB, Saenjan P. 2013. Soil properties and maize growth in saline and nonsaline soils using cassava-industrial waste compost and vermicompost with or without earthworms. Land Degradation \& Development. DOI: 10.1002/ldr.2208

Pearce JL, Venier LA, Eccles G, Pedlar J, McKenney D. 2004. Influence of habitat and microhabitat on epigeal spider (Araneae) assemblages in four stand types. Biodiversity and Conservation 13: 1305-1334.

Sanders D, Entling MH. 2011. Large variation of suction sampling efficiency depending on arthropod groups, species traits, and habitat properties. Entomologia Experimentalis et Applicata 138: $234-243$.

Scherber C, Eisenhauer N, Weisser WW, Schmid B, Voigt W, Fischer M, Schulze ED, Roscher C, Weigelt A, Allan E, Bessler H, Bonkowski M, Buchmann N, Buscot F, Clement LW, Ebeling A, Engels C, Halle S, Kertscher I, Klein AM, Koller R, König S, Kowalski E, Kummer V, Kuu A, Lange M, Lauterbach D, Middelhoff C, Migunova VD, Milcu A, Müller R, Partsch S, Petermann JS, Renker C, Rottstock T, Sabais A, Scheu S, Schumacher J, Temperton VM, Tscharntke T. 2010. Bottom-up effects of plant diversity on multitrophic interactions in a biodiversity experiment. Nature 468: 553-556.

Silva DKA, Freitas NO, Sousa RG, Silva FSB, Araújo ASF, Maia LC. 2012. Soil microbial biomass and activity under natural and regenerated forests and conventional sugarcane plantations in Brazil. Geoderma 189: 257-261.

Souza Braz AM, Fernandes AR, Alleoni LRF. 2013 Soil attributes after the conversion from forest to pasture in amazon. Land Degradation \& Development 24: 33-38. DOI: 10.1002/ldr.1100

Thomaz EL, Luiz JC. 2012 Soil loss, soil degradation and rehabilitation in a degraded land area in Guarapuava (Brazil). Land Degradation \& Development 23: 72-81. DOI: 10.1002/ldr.1052

Trabaquini K, Formaggio AR, Galvão LS. 2013. Changes in physical properties of soils with land use time in the Brazilian savanna environment. Land Degradation \& Development. DOI: 10.1002/ldr.2222 


\section{A. S. F. DE ARAÚJO ET AL.}

Trager MD, Bhotika S, Hostetler JA, Andrade GV, Rodriguez-Cabal MA, McKeon CS, Osenberg CW, Bolker BM. 2010. Benefits for plants in ant-plant protective mutualisms: a meta-analysis. PLOS One 5: e14308.

Uetz GW. 1991. Habitat structure and spider foraging. In Habitat Structure: The Physical Arrangement of Objects in Space, McCoy ED, Bell SS, Mushinsky HR (eds). Chapman and Hall: London; 325-348.

Wall DH, Bardgett RD, Kelly E. 2010. Biodiversity in the dark. Nature Geoscience 3: 297-298.

Wardle DA, Bardgett RD, Klironomos JN, Setälä H, van der Putten HV, Wall DH. 2004. Ecological linkages between aboveground and belowground biota. Science 304: 1629-1633.
Weber NA. 1966. Fungus-Growing Ants. Science 153: 587-604

Wise DH, Chen B. 1999. Impact of intraguild predators on survival of a forest-floor wolf spider. Oecologia 121: 129-137.

Wolters V. 2001. Biodiversity of soil animals and its function. European Journal of Soil Biology 37: 221-227.

Wu JP, Liu ZF, Sun YX, Zhou LX, Lin YB, Fu SL. 2013 Introduced Eucalyptus urophylla plantations change the composition of the soil microbial community in subtropical China. Land Degradation \& Development 24: 400-406. DOI: $10.1002 /$ ddr.2161

Yeomans JC, Bremner JM. 1988. A rapid and precise method for routine determination of organic carbon in soil. Communications in Soil Science and Plant Analysis 19: 1467-1476. 